Nina Vodopivec

\title{
Družbene solidarnosti $v$ času socialističnih tovarn in individualizacije družbe
}

Ključne besede: družbena solidarnost, tekstilne delavke, socialistična tovarna, organizacija in ideologija dela, postsocialistične spremembe

DOI: 10.4312 /ars.8.1.136-150

»Sem večkrat povedal na sestankih, na zborih delavcev, da tale naš raufenk morate gledati, pa ga imeti radi, ta nam daje kruh in če bomo znali, bomo tudi uspeli, vsi bili zadovoljni in srečni. « Tako je najin pogovor začel nekdanji direktor Predilnice Litija majskega dne leta 2005. Upokojenec, ki je kot direktor predilnico vodil skoraj 30 let, je najprej poskušal »utrditi pripadnost delavcev tovarni«. Ob tem se je skliceval na tovarniški dimnik. Dimnik uteleša produkcijsko moč v smislu klasične industrializacije, socialistične ideologije in modernizacije. Nekdanji direktor je opozoril, da je bilo treba pripadnost tovarni v petdesetih letih prejšnjega stoletja šele vzpostaviti, pomen dimnika $\mathrm{v}$ krajini tovarniške skupnosti šele zgraditi. V nadaljevanju bom takšne politike, načrte in prakse, ki so vzpostavljali raznolike pripadnosti, navezala na koncept solidarnosti. Najprej se bom sklicevala na pomen tovarne in industrijskega dela v socialističnem času, nato na postsocialistično preoblikovanje ${ }^{1}$ in na neoliberalno paradigmo samoodgovornosti.

\section{Tovarniška skupnost kot prostor za solidarnost}

Tovarna je bila $\mathrm{v}$ socializmu zamišljena kot pomembno središče socialne in kulturne modernizacije. $\mathrm{V}$ takšnih načrtih je bila modernizacijski motor za osveščanje okoliškega, ponavadi pretežno ruralnega prebivalstva. Kljub ideološko političnim načrtom pri tem ni šlo zgolj za politično propagando, predvsem pa ti procesi s strani lokalnega prebivalstva niso bili percipirani kot takšni.

Socialistične tovarne so zaznamovale življenja različnih generacij iste družine ter samo lokalno skupnost. Tovarne so gradile stanovanjske bloke, organizirale izlete, družabne dogodke, s počitniškimi domovi na morju in v hribih so organizirale prosti čas zaposlenih in njihovih družin. Tovarna ni bila zgolj delovni prostor, temveč prostor, kjer so se ljudje spoznavali z drugačnim načinom življenja. Za marsikoga je bila tovarna

1 Sklicujem se na terensko delo v proizvodnji Predilnice Litija in intervjuje $\mathrm{z}$ upokojenimi, brezposelnimi in še zaposlenimi v slovenski tekstilni industriji med letoma 2000 in 2011. 
mamljiva zaradi reševanja stanovanjskega vprašanja. Sindikalna potovanja in izleti so se ljudem močno vtisnili v spomin, nekateri so prvič v življenju odpotovali na morje ali v tujino. Tovarne so izdajale tovarniške glasnike, kjer so poročali o tehnoloških novitetah, objavljali poročila $\mathrm{z}$ izletov in zgodbe upokojencev, predstavljali osebne zgodbe ter hkrati informirali o dogajanju in delovanju tovarne (pregled po glasilih kaže, da je bil večji del besedila namenjen predvsem povezovanju $\mathrm{z}$ delavci). Predilnica Litija je na primer izdala tri monografije o tovarni. Vsaka delavka oziroma delavec je imel doma vsaj eno teh knjig. S ponosom so listali po njej in mi kazali fotografije, ko sem jih obiskala na domu. Na njih so prepoznali sebe, svoje sorodnike in prijatelje. Zgodovinar Kresal, ki je uredil vse tri monografije, se spominja, da mu je pri urejanju gradiva nekdanji direktor predilnice rekel, naj se na fotografijah prepoznajo prav vsi delavci. Takšne prakse kažejo, da je vodstvo načrtno oblikovalo pripadnost in lojalnost zaposlenih tovarni ter da so vizijo prihodnosti vzpostavljali na kontinuiteti z ustvarjanjem tovarniške skupnosti.

Tovarne so z oblikovanjem infrastrukture kraja in s strukturiranjem delovnih prostočasovnih dejavnosti organizirale življenja precej širšega kroga ljudi od zaposlenih in njihovih družin. Tovarniške skupnosti so strukturirale in rutinizirale vsakdanje življenje, produkcijo, potrošnjo, reprodukcijo ter formalne in neformalne družbene mreže. Delovno mesto v tovarni je odigralo pomembno vlogo pri oblikovanju družbenih mrež, v družinskem življenju in pri integraciji v skupnost. Življenje v kraju je bilo skoncentrirano okoli tovarne; ko so politični funkcionarji prihajali v kraj, so obiskali tovarno, kar je dajalo vtis njenega velikega pomena. Tovarne so gradile sindikalne dvorane, kjer so potekale tudi lokalne proslave, organizirale so družabne dogodke ter imele svojo igralno in pevsko godbo. Ob večjih proslavah so se v tovarni zbrale različne generacije iste družine: vnuki, ki so nastopali v pevskih zborih, upokojeni delavci, s katerimi je tovarna ohranjala stike, in njihovi zaposleni otroci. Prakse, s katerimi so se vzpostavljale tovarniške skupnosti, niso krepile zgolj pripadnosti zaposlenih tovarni, temveč tudi sokrajanov, vezi med različnimi generacijami ter med tovarno in lokalno skupnostjo. Na tak način so se oblikovali prostori za solidarnost.

Solidarnost je osrednji koncept socialistične ideologije, družbenega samoupravljanja, gospodarske politike o razvitih in nerazvitih v Jugoslaviji, gibanja neuvrščenosti, ideologije dela ter komunalnih praks. Ena propagiranih oblik normativne solidarnosti je bilo tudi "prostovoljno« delo. Delo ni bilo prostovoljno $\mathrm{v}$ pravem pomenu besede, pa čeprav ga je marsikdo in marsikdaj tako čutil oziroma se ga tako spominja danes. S prostovoljnim delom ${ }^{2}$ so na primer v Velenju zgradili stadion, otroško igrišče, šolo, restavracijo, letni kino in počitniške hiške ter uredili

2 Število opravljenih prostovoljnih ur je zagotavljalo pridobitev stanovanjske pravice. Več ur si opravil, prej si prišel do stanovanja (Kladnik, 2013, 257). 
mestni park in okolico jezer. Prostovoljnega udarništva se je udeležil tudi sam direktor rudnika. Po njegovem pripovedovanju naj bi takšne oblike vplivale na odnose med delavci in jih »nevsiljivo povezale» (Kladnik, 2013, 257).

Jugoslovanski sistem je bil zanimiv za številne tuje strokovnjake kot laboratorij za preučevanje participatornih praks socialistične družbe, družbene lastnine in tržnega socializma. Za podrobnejšo analitično raziskavo bi bile potrebne etnografije samoupravnih praks in doživljanja. Mednarodna študija Howarda Wachtela je ena redkih (1973), ki na podlagi empiričnega gradiva različnih avtorjev kritično obravnava prakso samoupravljanja $\mathrm{v}$ jugoslovanskih tovarnah. Osredotoči se na moč odločanja $\mathrm{v}$ samoupravnem organu, v delavskem svetu. Njegova sinteza kaže, da večina industrijskih delavcev ni čutila močnega vpliva delavskega sveta in $s$ tem delavcev v podjetju. Po mnenju $42 \%$ intervjuvanih delavcev v 14 podjetjih v Ljubljani se samoupravni organi niso dovolj posvetovali z delavci. Študija štirih podjetij v Sloveniji je opozorila, da so imeli v podjetjih največ nadzora menedžerji, uprava in vodstvo. V vseh štirih tovarnah so menili, da bi delavski svet moral imeti največ vpliva. Diskrepanca med percipiranim in dejanskim vplivom je bila največja pri nekvalificiranih delavcih in najmanjša pri menedžerjih. Delavci pa naj bi si, po anketah sodeč, želeli vpliva predvsem pri delovnih pogojih, delovnih razmerjih in osebnem dohodku, niso pa jih toliko zanimala širša vprašanja delovanja tovarne.

Zgodovinar Jože Prinčič je analiziral dinamiko med partijsko politiko in podjetništvom ter vlogo direktorja v socializmu (2008). Vprašanje je namreč bilo, kako v samoupravnem sistemu določiti položaj direktorja: direktorjeva vloga naj bi bila (za politiko) premočna in je zmanjševala vlogo samoupravnih organov. V svoji analizi prikaže, kako so od šestdesetih let naprej podjetja pridobivala avtonomnejši položaj, osrednja pri oblikovanju profila podjetja pa je bila direktorjeva ekipa, čeprav so jo morali formalno potrditi delavski sveti. Nekdanji direktor tekstilne tovarne, s katerim sem se pogovarjala leta 2001, je delavski svet opisal kot organ, kjer je moral zagovarjati svoje odločitve ter delavce prepričati o njihovi pravilnosti. Takšna izjava nakazuje, da je bila odločitev sicer direktorjeva, a jo je bilo treba zagovarjati.

Moje sogovornice niso posebej izpostavljale institucije samoupravljanja. Predvsem mlajše (po vojni rojene generacije) so ob omembi delavskih svetov pogosto zamahnile $\mathrm{z}$ roko ali pokomentirale, da je to pomenilo več sestankov, konfliktov in pregovarjanj zaradi nepomembnih reči. Ne glede na reakcijo to ne pomeni, da se ljudje na samoupravne ideje niso sklicevali. Pri tem pa ni šlo za moč odločanja v delavskih svetih, temveč za transparentnost delovanja tovarne in zaščite kolektivnih pravic.

Institucije samoupravljanja in delavske svete so v pogovorih pogosteje izpostavile starejše upokojene delavke, ki so se zaposlile po vojni, sindikalisti ali nekdanji 
direktorji. Nekatere so bile prepričane, da je bilo v preteklosti zaradi takšnih institucij "vse javno in so lahko vse povedale«. Spet druge, predvsem po vojni rojene generacije, pa so zagotavljale, da je bilo vse prikrito in se nič ni vedelo, predvsem pa ničemur nisi smel ugovarjati, pa ne zaradi politične represije, temveč zaradi hierarhije in organizacije $\mathrm{v}$ tovarni.

Kljub temu, da so sogovorniki socializem označili kot sistem večje enakosti med ljudmi, to ni pomenilo, da v govoru o preteklosti niso omenjali hierarhij ali avtoritetnega odnosa. Ljudje so ponotranjili neenakosti med hierarhičnimi položaji, organizacija dela, ki je vzpostavljala hierarhijo, se jim je zdela samoumevna (pa čeprav so bili do nje tudi kritični), razlike v plačah se jim niso zdele samoumevne in jih tudi danes ostro zavračajo. Plače so bile nekdaj v razmerju ena proti štiri, so v pogovorih izpostavile sogovornice, "plačilna lista, kjer smo videli plačo direktorja, [pa je] včasih visela na oglasni deski«.

Starejše upokojene generacije zaposlenih so $\mathrm{v}$ pogovorih preteklo tovarniško življenje pogosto upodabljale $\mathrm{z}$ družinskimi metaforami, vsakdanje medsebojne odnose v tovarni pa $\mathrm{z}$ družinskim življenjem. »Res tako smo bili v fabrki kot ena družina, « je komentirala starejša upokojenka. ${ }^{3} \mathrm{~V}$ opisovanju svojega odnosa do zaposlenih pa je družinske metafore uporabljal tudi nekdanji direktor predilnice: »Mi je bila tovarna moj prvi dom, žena in otroci pa drugi.« Nekdanji direktorji tekstilnih tovarn so v pogovorih poudarjali svojo odgovornost in skrb za delavce, zlasti za ženske. Pretekli odnos med direktorji, delavkami in tovarno gre brati $\mathrm{v}$ kontekstu socialističnega paternalizma.

Starejša upokojena uslužbenka se je spominjala, kako je tovarna pomagala »otroke gor spraviti«:

Fabrika je dala zatočišče otrokom fabričanov, ko otroci niso delali šole, so mame prišle $\mathrm{k}$ direktorju nesrečne in jih je direktor vzel na delo. Koliko je fabrika takih izgubljenih otrok vzela pod okrilje in jih tako rešila. Kasneje jih je štipendirala, veliko so jih na prakso vzeli ali pa med počitnicami. ${ }^{4}$

Kot ugotavljam (Vodopivec, 2012a), niso zgolj mediji direktorje portretirali kot očete, ki so poskrbeli za blagostanje otrok zaposlenih, temveč tudi starejše upokojene delavke in uslužbenke. Socialistični paternalizem ni deloval represivno, ljudje so ga razumeli kot skrb tovarne za delavce.

Politike oblikovanja tovarniških skupnosti so se spremenile $\mathrm{v}$ času postsocialističnega preoblikovanja, $\mathrm{s}$ pristopom $\mathrm{k}$ EU ter $\mathrm{z}$ intenzifikacijo in

3 Litija, 2003.

4 Litija, 2004. 
fleksibilizacijo dela. »Saj smo delniška družba, ${ }^{5}$ ampak nenazadnje večinski lastniki smo še vedno delavci pa penzionisti, « je komentiral vodja oddelka leta 2004, »jaz pravim, smo še vedno malo po ta starem. "Vendar je ob vprašanju, kaj naj bi to pravzaprav pomenilo, odvrnil:

Takrat (v socializmu) je bilo vse od vsakega, pa od nobenega nič. Zdaj je zasebna lastnina, če jih dvajset združi denar in vloži notri, to je njihovo. Ni družbeno, kot je bilo prej. Ampak jaz hočem našim delavcem vseeno na sestankih malo na dušo popihat in pravim, da je zdaj mogoče še bolj naše, kot je bilo prej. Prej ni bilo naše.

Interpretacije o tem, kaj je naše, pa so se spremenile. Koncept delniških družb se navezuje na ideje lastništva. Pri tem pa ne gre, da bi takšne občutke imeli ljudje v socialistični preteklosti. Pojmovanje "naša fabrka« se v interpretacijah socialistične preteklosti navezuje na pripadnost. »Smo imeli zelo občutek, da je naša fabrika. Nam je pomenilo, da je dobro delala, « je v intervjuju rekla nekdanja predilniška proizvodna delavka in poudarila, da so včasih verjeli, da se jim je zaupalo, in da so tudi sami zelo zaupali vodstvu.

Spremenjeni položaj delavke in delavca $\mathrm{v}$ sodobnem vsakdanjem socialnem življenju je postavljen $v$ drugačen diskurz o razmerju neenakosti in moči. Razmejevanja med $m i$ in oni se v takšnem kontekstu pogosto kažejo v delitvi na tovarno in delavce. Tovarno, o kateri so bili delavci navajeni govoriti kot o naši tovarni, v tem primeru postavijo v svojo opozicijo. Očitki so usmerjeni proti »koruptivnim mladim menedžerjem« in državi, ki manevre podpira.

\section{Ideologija in organizacija industrijskega dela}

Pomembno vlogo pri oblikovanju raznolikih pripadnosti je odigrala ideologija industrijskega dela. Pri tem ne mislim zgolj na socialistično ideologijo in družbeno samoupravljanje. Delo je namreč več kot tehnološki proces, racionalna ali tekmovalna dejavnost, podrejena kapitalu ali politični ideologiji. Pomen industrijskega dela se konstituira v odnosu med strojem, okoljem in skupnostjo. Vrednost, ki se jo pripisuje delu, se vzpostavlja z oblikovanjem relacij med ljudmi, predmeti in različnimi okolji: na ravni tovarne, lokalne skupnosti in širše družbe. Izkušnje dela zaznamujejo spol, starost, razmerja lokalne skupnosti, družinske tradicije, vrednotenje in razumevanje spretnosti, spomini ter nacionalni in transnacionalni diskurzi industrijskega dela.

5 Predilnica Litija se je kot številna podjetja v Sloveniji lastninila z notranjimi odkupi, leta 1995 se je preoblikovala v delniško družbo in leta 2005 v družbo z omejeno odgovornostjo. 
Organizacija dela v tovarni ne vzpostavlja zgolj sistema produkcije, temveč oblikuje tudi delavske subjektivitete, odnose med ljudmi in različne pripadnosti. Organizacija je zaposlene v proizvodnji delila na tehnike, vodje in posluževalke strojev, na moška in ženska dela, predvsem pa je zaposlene močno zaznamovala delitev na proizvodnjo in pisarne.

Fizično delo za strojem na trgu dela danes ne kotira visoko. ${ }^{6}$ Poznavanje stroja, upravljanje $\mathrm{v}$ pravem pomenu besede, pa je $\mathrm{v}$ proizvodnji obdržalo določeno moč. Delo za strojem kaže na specifična znanja in spretnosti. V tem primeru izkušnje štejejo več kot šolsko znanje. $\mathrm{V}$ proizvodnji je utelešena dimenzija dela neposredna in očitna. Delo v proizvodnji zaznamujejo številne neverbalno artikulirane dimenzije, kar povezuje proizvodne tekstilne delavke med seboj in hkrati vzpostavlja specifične telesne spomine. To lahko zajame tudi številne telesne poškodbe, ki so prizadele delavke, ki so posluževale podobne stroje oziroma so delale $\mathrm{v}$ isti branži tekstilne industrije. $\mathrm{V}$ tem smislu gre za prepoznavanje občutij in izkušenj, znanj, kjer se je oblikovala povezanost in se je lahko vzpostavljala solidarnost. To sem ugotavljala tudi sama: ko sem začutila bolečine $v$ vratu, pekoče noge, od bombaža osušene oči, sem razumela marsikatero zgodbo, kar je tudi pri meni vzpostavljalo občutek povezanosti.

Socialistična ideologija je spodbujala tekmovanje med izmenami, predvsem pa je bilo pomembno, da je izmena dosegla normo. A vendar so bili v socialistični preteklosti poleg izmene normirani tudi posamezniki, zaradi česar je prihajalo do konfliktov, napetosti in tekmovanj. Norma je po pripovedovanju pogosto povezana $\mathrm{z}$ živčnostjo in strahom. Nekateri v pogovorih poudarjajo, kako je norma zagotavljala večjo pravičnost, saj je bil delavec $\mathrm{z}$ normiranim delom plačan glede na to, koliko je naredil. Pri tem so zgodbe tako o normi v preteklosti kot tudi o obstoju in normi $\mathrm{v}$ sedanjosti protislovne. Upokojene delavke so pripovedovale, kako včasih nekatere niti med malico niso hotele zapustiti delovnega mesta, da bi naredile čim več. Takšna zagnanost med delavci ni bila priljubljena. A po drugi strani so upokojeni naštevali primere tistih, ki se »za to niso trudile dovolj« in so še potem na stara leta odplačevale, saj so zaradi nedoseganja norme dobivale manjše pokojnine.

Čeprav so marsikatere delavke še danes jezne, da so bile norme v preteklosti previsoke, so vendar same razlagale, da sodelavke niso dosegle norme, ker so bile premalo pridne ali nesposobne. Norma je razmejevala ljudi, predvsem zaposlene $\mathrm{v}$ proizvodnji (razen vzdrževalcev) od vodij oddelkov in uslužbencev drugih služb v tovarni. Norma je onemogočala mobilnost in zapuščanje delovnih prostorov. Pri takšnem načinu plačevanja je pomembno vlogo odigrala navidezna samostojnost

6 Spretnosti tekstilne delavke imajo v industrijski krajini poseben pomen in vlogo, vežejo se na pojmovanje »ženskih spretnosti«. V proizvodnji tekstilne industrije so zaposlene predvsem ženske. Več o dimenziji spola, spretnosti in tekstilni industriji Vodopivec, 2010. 
normiranega dela; delavci so namreč za neuspeh krivili sebe (Burawoy, 1985, 171). Po drugi strani pa sta imela delavka in delavec prav zaradi navidezne samostojnosti normiranega dela občutek, da lahko sama organizirata in nadzorujeta delo.

Ko sem prišel v Perilo, je (to) šivala samo še ena starejša brigada, ki ni mogla več delati direktno v proizvodnji, so bili starejši, njihova norma (je bila) veliko znižana. To je bila takrat velika solidarnost fabrike. To so bili delavci pred penzijo, norma je bila, vendar se je to kompenziralo. Tega ni več. To je solidarnost, takrat so to delavci sklenili na delavskem svetu. ${ }^{7}$

Takšne oblike medgeneracijske solidarnosti pri delu, na katero se sklicuje Murin upokojeni delavec, pa niso vedno sprejele mlajše delavke. Nekatere so jezno pripovedovale, kako sta bila s tem izničena njihova trud in delo. ${ }^{8}$ To je poudaril tudi Murin upokojenec $\mathrm{v}$ nadaljevanju, ko je govoril o delu druge skupine, kjer je bila normirana posameznica: »Tu ni bilo solidarnosti, ker je imela vsaka svojo individualno normo in je bila po njej plačana.« Pripovedi o normah so raznolike in protislovne, vsekakor pa je norma močno zaznamovala tako izkušnje dela kot tudi pripadnost.

Delo v socialističnih tovarnah v Sloveniji je bilo podobno fordistični organizirani proizvodnji za tekočim trakom, a ju vendar ne gre povsem enačiti - prav tako kot jugoslovanske inačice samoupravljanja ne moremo popolnoma enačiti $\mathrm{z}$ drugimi socialističnimi tovarnami. Kljub specifikam jugoslovanskega samoupravljanja so tovarniške režime tudi v Jugoslaviji pogojevale politične odločitve, kvote, pomanjkanje strojne opreme in surovin, predvsem pa je socialistične tovarniške režime zaznamoval sistem mehkih proračunskih omejitev (Kornai, 1980). Takšne okoliščine so upravitelje socialističnih podjetij silile h kopičenju zalog ter k delovanju in razmišljanju o tem, kako si pridobiti nadzor nad viri. Pogajanja, do katerih je prihajalo med direktorji tovarn in državo (političnimi funkcionarji) ter med delavci in upravitelji, so rahljala centralizacijo moči v tovarni in hkrati na specifične načine vzpostavljala tovarniške skupnosti ter občutja solidarnosti s tovarno in zaposlenih med seboj.

Voditelji podjetij so $\mathrm{v}$ socialističnem režimu pomanjkljivosti tehnologije in surovin ter probleme zapletenih administracij reševali tudi s pomočjo številnih proizvodnih delavk in delavcev. Ob tem so se v tovarniških in industrijskih okoljih oblikovali specifični odnosi zaupanja, t. i. tihi pakti med tovarno in zaposlenimi, med delavci in nižjim menedžmentom v proizvodnji, ${ }^{9}$ ki so močno zaznamovali družbena

7 Murska Sobota, 2010. Za prepis pogovora se zahvaljujem kustodinji Pokrajinskega muzeja v Murski Soboti Jelki Pšajd.

8 Upoštevati moramo, da socializem ne pomeni homogene dobe, $\mathrm{v} 45$ letih je prišlo do številnih sprememb.

9 Po Burawoyu in Lukacsu posebna družbena pogodba (1992). 
razmerja, izkušnje tovarniškega dela in pripadnost tovarni. Takšni odnosi so delavcem zagotavljali, da so v zameno za nadure, težje delo in nižje plače dobili zagotovljena delovna mesta, stabilnost, socialno varnost, nagrade, delitev dobička ipd. in odprt dostop do drugih prostorov družbene mreže: do izobrazbe, stanovanja, pomoči družini in otrokom (pri štipendiranju, s poletnim delom ipd.), kar je bilo pomembno predvsem v kriznih trenutkih. Takšen sistem je bil mogoč zaradi notranjih režimov jugoslovanskega samoupravljanja in mehkih proračunskih omejitev (Stanojević, 2010). Samoupravne strukture so bile prepletene s tradicijo lokalnih skupnosti in polproletarskim načinom življenja ljudi. Številni delavci so obdržali nekaj zemlje oziroma so ob večjih sezonskih opravilih pomagali na kmetijah staršev oziroma sorodnikov. Takrat niso prišli v tovarno, kar je vodstvo v kontekstu že povedanega o $t$. i. tihem paktu toleriralo, prav tako kot tudi druge oblike popoldanskega dela. Formalna in neformalna ekonomija sta bili v socializmu tesno povezani, neformalna ekonomija je služila kot pomembno varnostno orodje. Temeljne pri neformalnih ekonomijah so bile prav družbene mreže, predvsem odnos reciprocitete in zaupanja.

Po Stanojeviću je bila $\mathrm{v}$ primerjavi $\mathrm{z}$ drugimi postsocialističnimi državami specifika slovenskega prostora (poleg pretekle politične situacije in že vzpostavljenih tržnih odnosov $\mathrm{z}$ zahodom) tudi $\mathrm{v}$ razmeroma učinkovitem interesnem organiziranju delavstva. Ob poglabljanju klasičnih tržnih koordinacijskih mehanizmov (znotraj podjetniških hierarhij in konkurenčnih tržnih aranžmajev) so se ohranjali in sistematično razvijali regulativni in redistribucijski mehanizmi, ki so sicer značilni za zahodnoevropske družbe: sistem centraliziranih inkluzivnih kolektivnih pogajanj ter sorazmerno razvit sistem socialne zaščite. V prvem obdobju družbeno-ekonomskega preoblikovanja po osamosvojitvi Slovenije so bili v redistribucijo nekdanje družbene lastnine vključeni vsi igralci: država (administrativna politika), delodajalci (menedžerji) in delavci (sindikati). Socialnega pakta je bilo konec po vstopu v EU, odnosi so se radikalizirali, hkrati se je povečala delovna obremenitev, prihajalo je do sistematičnega in dogovorjenega omejevanja rasti plač (Stanojević, 2010).

$\mathrm{Z}$ intenzifikacijo in fleksibilizacijo dela se je zmanjševal čas za pridobivanje dohodkov iz neformalnih virov. Potrebne bi bile bolj poglobljene raziskave, da bi ugotovili, kakšne neformalne mreže in oblike povezovanja prevladujejo danes in kako so strukturirane. Bežen pogled opozarja, da so se (z rastjo brezposelnosti in revnih zaposlenih) okrepile predvsem družinske vezi. Otroci ostajajo doma dalj časa, $s$ honorarnim delom sodelujejo pri dohodku gospodinjstva ali se kot odrasli vračajo domov, skrbijo za svoje starše oziroma živijo od njihove pokojnine.

$\mathrm{V}$ novem konkurenčnem kontekstu so se tovarne spremenile $\mathrm{v}$ organizacije $\mathrm{z}$ visoko obremenitvijo in fleksibilno proizvodnjo. Fleksibilizacija trga dela je povezana 
$\mathrm{z}$ redefinicijo dela. $\mathrm{S}$ funkcionalno in časovno fleksibilizacijo so se začele pojavljati različne nestandardne oblike zaposlovanja, ki so vzpostavljale sistem neprestane negotovosti. Imperativ sodobne reorganizacije dela je konkurenčnost: na trgu dela in $\mathrm{v}$ proizvodnji. Reorganizacija v proizvodnji postavlja delavce $\mathrm{v}$ odnose medsebojne konkurence.

Pogovori z nekaterimi odpuščenimi delavkami Mure kažejo, da sta se v zadnjih letih $\mathrm{v}$ proizvodnji povečala predvsem napetost in nezaupanje med sodelavkami $\mathrm{v}$ proizvodnji. Izguba zaupanja med delavci privede do zmanjšanja socialnega kapitala $\mathrm{v}$ kolektivu in posledično $\mathrm{v}$ širšem okolju. V kraju, kjer se ljudje med seboj poznajo, napetost in nezaupanj ne vzpostavljata problema le na delovnem mestu, temveč tudi $\mathrm{v}$ lokalni skupnosti. Menedžerji so se predvsem v izvoznem delu gospodarstva, v organizacijah $\mathrm{z}$ visoko obremenitvijo, po spremembi sistema najprej lotili zaostrovanja notranjih regulativnih mehanizmov. $\mathrm{V}$ proizvodnji je to lahko pomenilo, kot je komentirala Silva, nekdanja delavka Mure, da so bili delovni postopki pogosto le teoretično izmerjeni, nihče ni fizično poskusil, ali je delo sploh izvedljivo. V delovni čas in $\mathrm{s}$ tem $\mathrm{v}$ normirano delo niso bile vštete priprave (različni materiali zahtevajo različne stroje, priprava za to vzame čas), prav tako ne čas, ko so delavke čakale na materiale oziroma na popravilo stroja $\mathrm{v}$ primerih okvare. Delavke dela pogosto niso mogle opraviti dovolj hitro, saj je primanjkovalo potrošnega materiala, medtem pa so se višale norme. Delovne postopke so oteževale tudi prostorske razmere: "Nismo si mogle urediti, da bi nam klima delala, čeprav bi morali zaradi blaga imeti pogoje. Vročina je bila, dvainštirideset stopinj [...] Zdaj smo vse alergične na slab zrak in na vročino. Zdaj me je komaj zebst začelo, ko sem že dve leti na borzi [dela].«10

Poleg reorganizacije dela $\mathrm{v}$ proizvodnji, ki je vzpostavljala napetosti in negotovosti na delovnem mestu, je poleg menedžerskih prevzemov pogosto prihajalo do izčrpavanja podjetij, zapirale so se tovarne, brezposelni delavci so se borili za pretekle neizplačane plače, odpravnine oziroma druge neizplačane družbene prispevke. Tretje obdobje sprememb na področju industrijskih razmerij sovpada s tretjim valom privatizacije, $\mathrm{z}$ radikalizacijo odnosov med delavci, delodajalci in državo ter vstopom v evroobmočje. Tretji val (menedžerski odkupi) nima le materialnih, temveč tudi močne psihološke učinke, saj so privatizacije dramatično poglobile nezaupanje v družbi (Stanojević, 2010, Lorenčičč, 2012).

Preoblikovane politike trga dela so redefinirale delavske subjektivitete. Socializem je industrijske delavce postavil v osrednji načrt modernizacije in družbenega razvoja. V luči sodobnih politik na trgu dela pa so reprezentirani kot socialni problem per se in ne kot gospodarski dejavnik (Kovačič, 2009, 10).

10 Intervju, Murska Sobota, junij 2011. Več o psihofizičnih posledicah prestrukturiranja Vodopivec 2012b. 
Zahteva po spreminjanju delavskih subjektivitet ne zajame zgolj industrijskih delavcev, temveč vse zaposlene (in nezaposlene). Tržna racionalnost, ki poziva $h$ konkurenčnosti, mobilnosti in prožnosti, zahteva posameznike, ki znajo ustvarjati svoja delovna mesta in skrbijo za svojo zaposljivost. V ospredju ni več zaposlenost, temveč zaposljivost oziroma spretnost preoblikovanja poklicnih profilov. Politike zaposlovanja diktira paradigma samoodgovornosti, ki je uzurpirala tudi področje socialnih in zdravstvenih pravic. Podjetništvo danes ne zajame le spreminjanja organizacijskih oblik oziroma poslovnih modelov podjetij, temveč $\mathrm{v}$ splošnem vzpostavlja ideal delovanja posameznika; posameznik naj postane dober upravitelj svojega življenja. Blaginja posameznika se $\mathrm{v}$ sodobnem času meri $\mathrm{z}$ njegovim uspehom in s kompetencami uspešnega samoupravljanja. To ni pomembno le za osebni profit, temveč za javni mir in družbeni napredek (Rose, 1998). Po paradigmi samoodgovornosti je posameznik odgovoren za svoj položaj v družbi: zanese naj se sam nase, družba (oziroma država) je tista, ki mu pri tem zgolj asistira. Lojalnost in pripadnost sicer ostajata pomembni kvaliteti posameznika, t. i. mehki veščini, ki ju mora posameznik osvojiti in tržiti (Vodopivec, 2012b), a nista več sestavni del politik oblikovanja tovarniške skupnosti, kot je veljalo v času socialističnih tovarn.

\section{Zaključek}

Pripovedi o solidarnosti v socialistični preteklosti so protislovne. Kljub temu, da v pogovorih ljudje deklarativno pogosto rečejo, da je bilo v socializmu več solidarnosti kot danes, takšnih fiksnih prostorov solidarnosti ni mogoče najti (v smislu, da bi jih ljudje vedno neposredno občutili kot takšne).

Daniel Barbu ugotavlja, da v socialistični Romuniji kljub propagandi ni bilo solidarnosti. Opozori pa, da moramo razmisliti tudi o časovno krajših, nomadskih oblikah solidarnosti; sklicuje se na čakalne vrste (Barbu, 1998, po Badica, 2012). Čeprav so bile osovražene, predmet kritik in posmeha, so vzpostavljale določeno obliko družbenosti, kjer se je krepila solidarnost čakajočih proti sistemu. Čakajoči so poročali o produktih ali si čuvali vrsto; gre za solidarnost, ki je delovala proti zunanjemu sovražniku - sistemu, državi, partiji. Kljub temu, da gre za Romunijo, kar je težko primerjati z vpeljavo in doživljanjem samoupravnega sistema v Sloveniji, se sklicujem na njegovo idejo nomadske solidarnosti v socializmu, ki se je tudi v Sloveniji pogosto kazala v pozi proti državi in njeni politiki (pa čeprav v ospredju samoupravnega sistema ni bila država, temveč družba). »Obvladovati sistem« oziroma »znajti se« je najpogostejši sklic številnih pripovedi in spominov. Socializem zaznamuje paradoks oziroma številna dvoumja: ljudje so podpirali temeljne vrednote in ideale, pa čeprav so njihove vsakdanje prakse kazale drugače (Yurchak, 2003, 484). 
V prispevku poskušam opozoriti na prostore, kjer je lahko $\mathrm{v}$ vsakodnevnem življenju prihajalo do časovno krajših oblik solidarnosti. Poleg normativne solidarnosti ter različnih političnih institucij, ideologij in njihovega vsakdanjega življenja sta svojevrstne prostore za solidarnost oblikovali socialistična tovarna in organizacija dela. Ob spominu na socialistično preteklost so delavci pripovedovali »o naši fabrki«, vanjo so verjeli, jo zagovarjali. A to ni pomenilo, da se na tovarno niso tudi jezili, iz tovarne odnašali materiale in jih uporabljali za zasebne potrebe, ideje skupnostnih akcij smešili in se nad njimi pritoževali. A vendar so hkrati s ponosom pokazali, do kod sežejo njihove investicije. Ljudje so številne kolektivne pravice dojeli kot samoumevne, ko jih ni bilo več, so se začeli nanje sklicevati. Industrijski delavci so se prepoznali $\mathrm{v}$ kolektivnem subjektu: kot promotorji družbenega razvoja in osrednjega političnega subjekta socialistične modernizacije, medtem ko se danes spopadajo $\mathrm{z}$ materialnim in simbolnim osiromašenjem. $\mathrm{S}$ paradigmo samoodgovornosti ni prišlo zgolj do premoščanja tveganj z družbe na posameznika, temveč se je predrugačilo tudi samo prepoznavanje njegove vloge: družbeni pogoji in okoliščine so se individualizirali in se kažejo kot rezultat posameznikove volje, izbire in sposobnosti. Položaj posameznika se je začelo brati kot odsev njegove kulture oziroma osebnih značilnosti. Ob tem je prihajalo do ponotranjenja krivde za svoj položaj.

Klasična delavska solidarnost je $\mathrm{v}$ zatonu, opozarjajo številni analitiki, prav tako sindikalna gibanja, organizirana solidarnost, ki je temeljila na državljanstvu, socialnih pravicah in medgeneracijski solidarnosti. Tisto, kar po Nancy Fraser združuje različne ljudi danes, ni skupno državljanstvo, nacionalna pripadnost ali gola medsebojna odvisnost, temveč skupna podrejenost strukturam vladanja: transnacionalnim organizacijam in korporativni logiki. Država se je odmaknila s področja socialne skrbi, v ospredje so politike postavile odgovornost posameznika. S preoblikovanjem se je individualiziralo razumevanje in prepoznavanje družbene pogojenosti. Ekonomizacija družbe in njena depolitizacija sta dekolektivizirali prostore, kjer bi bilo mogoče vzpostavljati solidarnost.

$\mathrm{V}$ tem vidim razliko in tudi problem sodobnega časa: $\mathrm{v}$ načinu prepoznavanja družbenega, $\mathrm{v}$ razumevanju družbe, ki je $\mathrm{v}$ kontekstu socialistične ideologije in vsakdanjega življenja v socializmu imela drugačno organizacijo, razlago in izkustvo. $\mathrm{V}$ takšnih okvirih bi bilo v nadaljevanju za oblikovanje solidarnosti zato predvsem pomembno prepoznati družbeno in politično konstruiranost ter $\mathrm{v}$ razpravo vrniti družbenost, da bi se lahko vzpostavili novi prostori za solidarnost. 


\section{Literatura}

Badica, S., Eating Well in Times of Scarcity: Reactions, Perceptions, and Negotiation of Shortages in 1980s' Romania, v: Negotiating Normality (ur. Koleva, D.), London 2012, str. 121-150.

Barbu, D., Destinul colectiv, servitutea involuntara, nefericirea totalitara: trei mituri ale comunismului românesc [Collective destiny, forced servitude, totalitarian unhappiness: three myths of Romanian communism], v: Miturile comunismului românesc [Myths of Romanian Communism], Bukarešta 1998.

Burawoy, M., The Politics of Production: Factory Regimes Under Capitalism and Socialism, London 1985.

Burawoy, M., Lukacs, J., The Radiant Past: Ideology and Reality in Hungary's Road to Capitalism, Chicago 1992.

Fraser, N., Scales of Justice: Reimagining Political Space in a Globalizing World, Cambridge 2008.

Kladnik, A., Oblikovanje in razvoj socialističnega mesta $\mathrm{v}$ Jugoslaviji in na Češkoslovaškem, 1945-1965. Doktorska disertacija, Univerza v Ljubljani, Ljubljana 2013.

Kornai, J., Economics of Shortage, Amsterdam 1980.

Kovačič, G., Kriza kot priložnost za revizijo medijskega sistema, Medijska preža 34 (35), 2009, str. 10.

Lorenčič, A., Prelom s starim in začetek novega: tranzicija slovenskega gospodarstva iz socializma $v$ kapitalizem (1990-2004), Ljubljana 2012.

Prinčič, J., Direktorska funkcija v jugoslovanskem socialističnem gospodarskem sistemu, v: Biti direktor v času socializma, med idejami in praksami (ur. Fikfak, J., Prinčič, J.), Ljubljana 2008, str. 57-102.

Rose, N., Inventing our Selves: Psychology, Power, and Personhood, Cambridge 1998.

Stanojević, M., The Europeanisation of Slovenian corporatism (the rise and decline of Slovenian corporatism: local and European factors), v: IREC 2010, Oslo, http:// www.fafo.no/irec/papers/miroslavStanojevic.pdf [19. 10. 2011].

Vodopivec, N., Textile workers in Slovenia: from nimble fingers to tired bodies, The anthropology of East Europe review 28 (1), 2010, str. 165-183.

Vodopivec, N.(a), On the road to modernity: textile workers and post-socialist transformations in Slovenia, History 97 (328), 2012, str. 609-629.

Vodopivec, N.(b), Preoblikovanje tovarniških režimov in nove delavske subjektivitete, Borec 64, 2012, str. 178-199. 
Wachtel, H., Workers' management and workers' wages in Yugoslavia: the theory and practice of participatory socialism, Ithaca, London 1973.

Yurchak, A., Everything Was Forever, Until It Was No More: Last Soviet Generation, Princeton, Oxford 2006. 
Nina Vodopivec

\section{Družbene solidarnosti v času socialističnih tovarn in individualizacije družbe}

Ključne besede: družbena solidarnost, tekstilne delavke, socialistična tovarna, organizacija in ideologija dela, postsocialistične spremembe

O solidarnosti razmišljam kot o družbeni solidarnosti. To odpira vprašanje o družbeni vključenosti in pripadnosti. Izhajam iz kritike sodobne ekonomizacije družbe in se zavzamem za to, da bi solidarnost mislili širše od ekonomske forme. Sklicujem se na organizacijo in ideologijo dela v socializmu, na pomen dela in socialistične tovarne, na njeno vlogo kot družbenega povezovalca oziroma oblikovalca skupnosti, njene infrastrukture, socialne ter simbolne krajine, na procese sodobnih političnoekonomskih preoblikovanj in individualizacije ter na paradigmo samoodgovornosti. V prispevku izhajam iz terenskega dela v Predilnici Litija in intervjujev s tekstilnimi delavkami, delavci, menedžerji in direktorji v Sloveniji (gradivo zbrano med letoma 2000 in 2011). Prispevek ni mišljen zgolj kot razmislek o solidarnosti v socialistični preteklosti in sodobnem času, temveč tudi kot možnost vzpostavljanja prostora za drugačne oblike solidarnosti v nadaljevanju. 
Nina Vodopivec

\section{Social Solidarities in the Times of Socialist Factories and Societal Individualization}

Keywords: social solidarity, textile workers, socialist factory, organization and ideology of labor, post-socialist changes

The paper discusses solidarity in the sense of social solidarity. The debate relates to issues of social inclusion and belonging. Departing from a critique of the economization of society, it considers solidarity in a sense that is broader than that of economic form. The paper refers to ideology and organization of labour in socialism, to meanings attributed to work as well as to the factor, to its role in constructing a community, its infrastructure, the social- and symbol-scape, to the changing relations between economy, market and state in the context of contemporary political and economic reconfigurations, to social transformations, and to processes of individualization within the self-responsibility paradigm. The paper is based on material gathered through field work (at the spinning factory of Litija) and interviews conducted with blue and white collar workers, directors and managers in Slovenia (between 2000 and 2011). The aim is to seek spaces for solidarity in socialism and in post-socialist time, and to see possibilities for thinking about it in the future. 